\title{
Corporate Social Responsibility in Commercial Banking - A Case Study from the Czech Republic
}

- Burianová Lenka, Paulík Jirí

\begin{abstract}
The concept of corporate social responsibility is not new in the banking sector, but nowadays, it becomes highly topical since the crisis has significantly highlighted the need for integration of moral principles in the banking business. Knowledge of business practice indicates the fact that the acceptance of moral principles in business is not integrated into management decisions of companies. It also cannot be accepted that self-regulatory instruments of companies such as CSR will be effective. The existing experience with the implementation of CSR and ethical principles in the banking sector leads to the opinion that the social responsibility of banks and ethics in banking sector are perceived as an appropriate marketing tool for public communication and are not integrated into policies of individual commercial banks. Experience with the crisis demonstrated that there is a lack of moral principles of managers' decisions. The aim of this article is to introduce theoretical aspects of CSR in commercial banking and measure the level of CSR in selected Czech commercial banks. In the article, the CSR index was calculated for Česká spořitelna, Československá obchodní banka, Komerční banka and GE Money Bank. Results of our research confirmed that the CSR index of selected Czech commercial banks achieves only an average level. There is a significant lack of transparent information in the context of CSR areas.
\end{abstract}

Keywords: Corporate Social Responsibility, CSR, commercial bank, CSR index.

JEL Classification: G21, Z13, M12, M14

\section{INTRODUCTION}

Financial crisis focused a public attention on the financial industry (San-Jose, Retolaza a Gutierrez-Goiria, 2011), because of the failure of commercial banks which has been transformed into a real economy. Also, the quality of hundreds of millions of people's lives around the world decreased through an increase of unemployment and due to a reduction of global consumption. In this process, total lack of decency to customers and companies (Graafland and Van de Ven, 2011; Fassin and Gosselin, 2011) played an important role in the moral failure of the financial system (Chatterjee and Lefcovitch, 2009).

Belas (2010) states that banking system is determined by factors that significantly affect the business of commercial banks such as the credibility of the banking sector; money as the business object and atypical structure of the balance sheet of commercial banks. These factors are a main reason for strict regulation of the banking sector.

Mejstř́k et al. (2008) presents a specific feature of banks within their safety net which includes state guarantees of banking business in the form of deposit insurance, function of central bank as a lender of last resort and doctrines such as "too big to fail". 
If a submitted argument about specific position of banks in the socio-economic system will be accepted, the issue of commercial banking in wider economic and social context has to be imperatively examined. Also, it may be naturally required a higher level of social responsibility for their business and a higher level of application of moral principles in a banking business.

This article is focused on a presentation of basic theoretical aspects of CSR concept in a commercial banking business and measurement of a level of CSR index in selected Czech banks.

\section{CORPORATE SOCIAL RESPONSIBILITY IN A COMMERCIAL BANKING}

Regard to the fact that CSR (Corporate Social Responsibility) is an abstract concept in a certain extent; no one could accurately define its borders yet. It does not exist any uniform definition. It is because the fact that companies does it voluntarily on its own beliefs or visions of profit. Socially responsible approach is not statutory. Individual forms of CSR concept is created always by a given company with its own stakeholders.

CSR concept includes economic, legal, ethical and philanthropic expectations that a society has in relation to a company (Classon and Dahlstrőm, 2006). According to Rendtorff and Mattson (2012), companies are perceived as human communities that use social practices in order to achieve common goals. These objectives are realized through bond of trust and authentic relationships with customers. The most important ethical principles that promote "good life of customers" are: customer's autonomy, dignity, honesty, customer's vulnerability that represents basic presumption for decent access to customers.

Yeung (2011) defines key element of CSR in the banking sector such as: understanding of financial services complexity, risk management, strengthen ethics in the banking business, strategy implementation for financial crisis, protection of customers' rights and channels settings for customer complaints.

Macdonald and Rundle-Thiele (2008) examined a relationship between CSR and customers' satisfaction in the bank. According to the conclusion of their study, customers' satisfaction is more affected by pro-client oriented events than CSR activities. And if the bank decides to develop CSR activities, focus of these activities has to be properly chosen.

Soana (2011) examined a correlation between social and financial performance of banks. This analysis showed that Italian banks haven't shown any significant correlation between social and financial performance. According to this study, any negative correlation between social and financial performance has not been revealed. On the other hand, results of this study provide evidence that banks' investment in CSR does not lead to economic benefits for the bank.

According to Graafland and Van de Ven (2011), focus on a social responsibility of the bank requires increased professionalism of those who are working in the financial sector; a stronger focus on compliance with Code of Ethics; verification of employees' capabilities and other approaches such as transparency, focus on stakeholders' interests and cooperation with social institutions. 
Robin (2008) states that society would like to have an economic system that creates opportunities for the growth of economic welfare and a happy life of people. The mission of ethics is to minimize the abuse of companies' power in the bilateral exchange relations and to reduce a negative impact on a people's daily live. A fundamental issue of business ethics is how to make capitalism more ethical. According to Sigurthorsson (2012), risk of CSR consists in the fact that it tends to become an excuse for soft law and corporate self-regulation. Icelandic banks implement their CSR concept through a financial support of charitable activities and they did not pay attention to a formation of socially responsible practices but reduced CSR tools only for public communication. Corporate social responsible practices should focus more on processes that make socially responsible profit and not on its distribution. Fassin and Gosselin (2011) reported that large institutions such as Fortis, Arthur Andersen \& Co. and AIG had a strong CSR and ethical culture but they have gone bankrupt anyway. These cases show a discrepancy between official pronouncements and procedures of senior management.

According to Palomino and Martinez (2011), the effectiveness of ethics programs is different in banks. Some programs are primarily aimed at achieving a favorable image in relation to socioeconomic institutions (government, media, society, customers) and they have not significant effect on the ethics of employees.

According to Gibbons (2011), many banks in United Kingdom do not act transparently. A scope of provided information is no sufficient, quality information absent for people who have financial difficulties etc. Tea, Paulišič, Krstinič-Nižič (2011) indicate that honesty, awareness, responsibility, creativity, objectivity and professionalism absent in the banking culture.

According to study of Pérez and Del Bosque (2012) which focused on Spanish banking institutions, banks tend to promote only those activities through CSR from which generally the greatest benefit have. In the banking sector, there are three basic groups: customers whom banks try to meet their financial needs; employees whom banks try to create a perfect working conditions to achieve their satisfaction and at last community (bank's surrounding) where banks contribute to a sustainable growth. In the area of CSR activities, Pérez and Del Bosque (2012) accuse banks of short-term improvement of bank's image and profit increase. According to authors, it is necessary to incorporate a social responsibility into organization's image and into a long-term strategy to reduce skepticism. Authors report that banking sector suffered large scratches on its image and credibility because of its integral participation in economic crisis. CSR concept is perceived as the most effective tool to improve reputation.

Watkins (2011) states that banking system is a typical capitalist activity which aims to a profit. Policy of laissey-faire believes that individuals and companies may seek to increase their financial wealth without any restrictions. Financial market presents unlimited opportunities for growth in financial wealth.

Based on results of empirical research, Chih, Chih and Chen (2010) indicate that larger companies are more oriented on CSR and the fact that financial performance and CSR are not together mutually related. Higher financial performance means that a company has a lot more available funds for CSR activities. There is a direct correlation between the overall health of the economy and a level of CSR in the company. If the economy is in a bad condition for example inflation is 
high, productivity growth or consumer confidence has a low level, companies do not have a vision to achieve profit in the near future and therefore they do not behave as socially responsible as in the area of economic optimism. The relationship between competition and CSR level is not linear. This means that the competition that is too low or too intense has a negative effect on CSR in the company. In a highly competitive environment, companies are trying to save resources because of their low profit margins. Conversely in the area where the competition does not exist, the environment does not force companies to build competitive advantage because trading partners does not have a choice among many alternatives. According to authors, companies made more socially responsible activities to gain competitive advantage in the area of more intense competition on the market. A higher level of self-regulation in the financial sector has a significantly positive effect on CSR. Companies behave more socially responsible in countries where relationships between employees and employers are characterized by cooperation where the management schools and macroeconomic environment are better.

Goss and Roberts (2011) investigated the relationship between CSR and a cost of banks' loans. Actually, banks meet a supervisory role over companies. Within a credit approval process and subsequent verification, banks gain much more information about the company than other interested parties on the market. Therefore they are best placed to assess the level of socially responsible activities undertaken by the company. Authors found that companies that have problems with CSR pay for loans of 7-18 basis points more than social responsible companies. Companies' investments to CSR reduced their volatility and thereby increased their attractiveness as a potential borrower.

Lenders are more sensitive to CSR activities of debtor in the area of less secure environment. The research also showed that less creditworthy borrowers who engage voluntarily in CSR activities have higher credit spreads and shorter maturity of loans. In this case, banks consider CSR investments as an unnecessary dispersion of corporate resources which increases a risk of the company. Result of increased risk is translated to higher borrowing costs.

According to Chatterjee and Lefcovitch (2009) managers' dilemma lies in the fact that which of CSR concepts are more important for the company than corporate responsibility (profit maximization). Principal responsibility of managers is in relation to shareholders. Managers may be satisfied if a minimal and law required level of CSR is achieved. Banks are dominantly oriented to maximize profits and totally ruthless in their activities in relation to interest of depositors, investors and general public. Banks violate the law, regulatory rules and code of ethics in order to maximize their own profit. According to Fassina (2011) the more bankers spoke about the social responsibility, the more they focused on increasing of shareholder value and their own personal bonuses and the height of "golden parachutes".

According to Chatterjee and Lefcovitch (2009), the importance of ethical standards for a financial market consists in the fact that financial markets works with money of other owners and the risk can bring profit but also losses. Too high risk has to be minimized for two reasons. First, it must be maintained a confidence in an investment. Second, undertaken risk may not mean a dangerous investment. 
In the context of financial crisis, discussion about a moral aspect of banking industry is still more intense. Banking sector is often considered to be an amoral area (Icke, B., T., Caliscan, Ayturk, Icke, M. A., 2011), which is primarily focused on a risk and revenues.

Paulet (2011) states that a banking area is not situated in ethically free area. According to the author, financial crisis shows that aggressive capitalism has demonstrated its limits. Regulations system must be supplemented by a transparency and moral aspects. To create a sustainable strategy means to define capitalism by new way through efficiency criteria which focus not only on a financial performance but also on economic and social conditions that guarantee better distribution of welfare to people.

In this context, it is evident that research in the area of CSR activities of commercial banks represents a current theoretical issue that has to be solved by a theoretical sphere.

Our research has focused on a measurement of CSR index in selected Czech banks through a methodology based on a KOPR method.

\section{THE CASE STUDY: THE LEVEL OF CSR IN SELECTED CZECH BANKS}

\subsection{The aim and methodology}

The aim of this research was to measure the level of CSR in selected Czech banks through CSR index and then data submit to the Cluster analysis.

Resulting framework for the measurement and evaluation of social responsibility in commercial banking of the Czech Republic has become the KOPR method which has been developed by the Association of Fair Business (Sdružení Korektní podnikání) (Plášková, 2009) but considerably modified by techniques of objective estimation.

In this assessment, basic pillars of a social responsibility (economic, social and environmental) are divided to eight areas comprising a total of 26 criteria which are subject to a scoring on a scale from 0 to 100 . The scoring applies particularly to provide information about a given area and criteria, to an evidence of activity in a given area of CSR, to the level of involvement of banks compared to other banks and results that were managed to report by social responsible activities.

Notes to the scoring assessment:

0 to10 points means that there is no information about the area, no evidence of socially responsible activities, and no data;

11 to 40 points means that there is missing information about a given area, some evidence pertaining to a relevant area, results show negative trend or do not meet objectives and lagging behind the other banks in a given area;

41 to 70 points means that there is the occurrence of sufficient knowledge of the area, convincing evidence regarding the relevant areas, results show insignificant but increasing trends, objectives are met, there is above average status in comparison with other banks;

71 to 100 points means there are very detailed information about a given area, very compelling 
evidence of the relevant area; there have been achieved sustainable results and dominant position in a given area in comparison to other banks.

Analyzed sample represents four largest domestic banks by a number of clients - Česká spořitelna (ČS), Československá obchodní banka (ČSOB), Komerční banka (KB) a GE Money Bank (GE). The aim of this analysis is to determine the CSR index for each bank, i.e. the calculation of the average scoring for all criteria. The concept of social responsibility receives an appropriate quantitative form by creating a CSR index.

The scoring has been conducted on an analysis of available information through a method of objective estimation.

This analysis uses public available sources - annual reports for a year 2011 and 2012, reports on a corporate social responsibility in 2011 and current information from the website.

\subsection{Results of CSR assessment in selected banks and discussion}

Basic pillars of CSR as Economy, Environment and Social Responsibility were evaluated separately and divided into eight main areas such as Management of CSR, Direct economic effects on a community, Indirect economic effects on the community, Human Rights, Social Policy, Employment, Consumer Protection and Environmental Policy.

CSR index for selected banks has been calculated through equations (1) and (2) as follows:

$C S R_{\text {index }}=\left(A_{5}+B_{3}+C_{3}+D_{3}+E_{2}+F_{5}+G_{3}+H_{2}\right) / 8$

$C S R_{\text {index }}=\left(\frac{\sum_{a=1} A}{5}+\frac{\sum_{b=1} B}{3}+\frac{\sum_{c=1} C}{3}+\frac{\sum_{d=1} D}{3}+\frac{\sum_{e=1} E}{2}+\frac{\sum_{f=1} F}{5}+\frac{\sum_{g=1} G}{3}+\frac{\sum_{h=1} H}{2}\right) / 8$

Economy

Management of CSR (A)

Tab. 1 - Evaluation criteria in the Management of CSR. Source: own.

\begin{tabular}{|c|c|c|c|c|c|c|c|c|}
\hline Criterion & \multicolumn{2}{|c|}{ Čs } & \multicolumn{2}{|c|}{ ČSOB } & \multicolumn{2}{|c|}{$\mathrm{KB}$} & \multicolumn{2}{|c|}{ GE } \\
\hline $\begin{array}{l}\text { Appointment of } \\
\text { CSR representatives } \\
\text { (A1) }\end{array}$ & 60 & $\begin{array}{l}\text { Information } \\
\text { about CSR } \\
\text { representa- } \\
\text { tives but not } \\
\text { too much } \\
\text { information } \\
\text { about ap- } \\
\text { pointment }\end{array}$ & 70 & $\begin{array}{l}\text { Detailed } \\
\text { informa- } \\
\text { tion about } \\
\text { the precise } \\
\text { procedure } \\
\text { for appoint- } \\
\text { ment }\end{array}$ & 30 & $\begin{array}{l}\text { Some in- } \\
\text { formation } \\
\text { but not so } \\
\text { valid in } \\
\text { compari- } \\
\text { son with } \\
\text { ČS and } \\
\text { ČSOB; no } \\
\text { informa- } \\
\text { tion about } \\
\text { CSR repre- } \\
\text { sentatives }\end{array}$ & 0 & $\begin{array}{l}\text { No } \\
\text { information }\end{array}$ \\
\hline
\end{tabular}




\begin{tabular}{|c|c|c|c|c|c|c|c|c|}
\hline $\begin{array}{l}\text { Determination of a } \\
\text { scope of authority, } \\
\text { strategies and } \\
\text { objectives of CSR } \\
\text { (A2) }\end{array}$ & 80 & $\begin{array}{l}\text { Special } \\
\text { document of } \\
\text { strategy for } \\
2011-2013 \text {, } \\
\text { but not much } \\
\text { information } \\
\text { about strategy } \\
\text { for next pe- } \\
\text { riod }\end{array}$ & 60 & $\begin{array}{l}\text { Well } \\
\text { described } \\
\text { strategy for } \\
2013 \text { but no } \\
\text { information } \\
\text { about strat- } \\
\text { egy for next } \\
\text { period }\end{array}$ & 50 & $\begin{array}{l}\text { Not too } \\
\text { much and } \\
\text { valid infor- } \\
\text { mation in } \\
\text { compari- } \\
\text { son with } \\
\text { ČS or } \\
\text { ČSOB }\end{array}$ & 10 & $\begin{array}{l}\text { No detailed } \\
\text { long-term } \\
\text { strategy }\end{array}$ \\
\hline $\begin{array}{l}\text { Documents and } \\
\text { records about CSR } \\
\text { (A3) }\end{array}$ & 90 & $\begin{array}{l}\text { Very detailed } \\
\text { information } \\
\text { about CSR on } \\
\text { website and } \\
\text { in Corporate } \\
\text { Social Re- } \\
\text { sponsibility } \\
\text { Report }\end{array}$ & 60 & $\begin{array}{l}\text { Good infor- } \\
\text { mation about } \\
\text { CSR on } \\
\text { website and } \\
\text { in special re- } \\
\text { port but not } \\
\text { so detailed in } \\
\text { comparison } \\
\text { with ČS }\end{array}$ & 50 & $\begin{array}{l}\text { Some in- } \\
\text { formation } \\
\text { on website } \\
\text { and men- } \\
\text { tion about } \\
\text { CSR in } \\
\text { Annual } \\
\text { report }\end{array}$ & 20 & $\begin{array}{l}\text { Not detailed } \\
\text { information } \\
\text { on website, } \\
\text { small men- } \\
\text { tion about } \\
\text { CSR in An- } \\
\text { nual report }\end{array}$ \\
\hline $\begin{array}{l}\text { System of } \\
\text { improvements (A4) }\end{array}$ & 40 & $\begin{array}{l}\text { Mention } \\
\text { about imple- } \\
\text { mentation of } \\
\text { Kaizen and } \\
\text { Six Sigma, } \\
\text { but no infor- } \\
\text { mation about } \\
\text { achievements }\end{array}$ & 0 & $\begin{array}{l}\text { No informa- } \\
\text { tion }\end{array}$ & 30 & $\begin{array}{l}\text { Just gener- } \\
\text { al mention } \\
\text { about some } \\
\text { improve- } \\
\text { ments, no } \\
\text { informa- } \\
\text { tion about } \\
\text { achieve- } \\
\text { ments }\end{array}$ & 0 & $\begin{array}{l}\text { No } \\
\text { information }\end{array}$ \\
\hline $\begin{array}{l}\text { Audits and } \\
\text { evaluation system } \\
\text { (A5) }\end{array}$ & 0 & $\begin{array}{l}\text { No informa- } \\
\text { tion }\end{array}$ & 20 & $\begin{array}{l}\text { Monitoring } \\
\text { according to } \\
\text { a Standard } \\
\text { corporate } \\
\text { responsibil- } \\
\text { ity, but no } \\
\text { information } \\
\text { about any } \\
\text { results }\end{array}$ & 10 & $\begin{array}{l}\text { Monitoring } \\
\text { taken from } \\
\text { owner } \\
\text { Société } \\
\text { Géné- } \\
\text { rale, no } \\
\text { informa- } \\
\text { tion about } \\
\text { results }\end{array}$ & 20 & $\begin{array}{l}\text { Monitoring } \\
\text { according to } \\
\text { a Standard } \\
\text { corporate } \\
\text { responsibil- } \\
\text { ity, but no } \\
\text { information } \\
\text { about any } \\
\text { results }\end{array}$ \\
\hline $\begin{array}{l}\mathrm{A}=(\mathrm{A} 1+\mathrm{A} 2+\mathrm{A} 3+\mathrm{A} 4+\mathrm{A} 5) \\
/ 5\end{array}$ & & 54 & & 42 & & 34 & & 10 \\
\hline
\end{tabular}

Within the Management of CSR, Česká spořitelna dominates over other banks where its CSR strategy is intertwined through entire Corporate Social Responsibility Report and provides the most information about socially responsible activities of the bank. Within the criteria "Appointment of CSR representatives", ČSOB has slightly better rating and its Policy of Sustainable Development presents a process by which complaints related to CSR leads to the General Director who is responsible for the social responsibility of the bank. Firstly, groups of experts verify a feedback from the external and internal environment. This group makes a decision to adopt the project and provide results to Management Team for Sustainable Development. This management team reports directly to the CEO and Board of Directors. Česká spořitelna as well as Komerční banka uses ombudsman to create an impression of CSR leaders. In the Česká spořitelna CEO Pavel Kysilka is responsible for a social responsibility. He was awarded several times already as the best banker of the year in nomination of Fincenteum's Bank of the Year. GE 
Money Bank operates by a weaker impression compared to other rated banks. GE Money Bank does not have any detailed long-term strategy and does not specify any CSR leaders despite all its CSR activities it has.

\section{Direct economic effects on a community (B)}

Investment to CSR of the bank is directly related to an economic performance. Therefore it is desirable to achieve satisfying financial results for the development of CSR and philanthropic activities. One part of direct economic impacts represents also approaches to employees' and suppliers' selection. These areas should definitely belong to the strategic reconsideration about CSR and a sustainable development of commercial banks.

Tab. 2 - Evaluation criteria in the area of direct economic effects on a community. Source:

\begin{tabular}{|c|c|c|c|c|c|c|c|c|}
\hline Criterion & \multicolumn{2}{|l|}{$\check{C} S$} & \multicolumn{2}{|c|}{$\check{\mathrm{CSOB}}$} & \multicolumn{2}{|c|}{ KB } & \multicolumn{2}{|c|}{ GE } \\
\hline $\begin{array}{l}\text { Direct } \\
\text { economic } \\
\text { results (B1) }\end{array}$ & 80 & $\begin{array}{l}\text { The best eco- } \\
\text { nomic results } \\
\text { in period } 2010 \\
\text { - } 2012 \text { in com- } \\
\text { parison with } \\
\text { other banks }\end{array}$ & 70 & $\begin{array}{l}\text { The sec- } \\
\text { ond best } \\
\text { economic } \\
\text { results in } \\
\text { period } 2010 \\
\text { - } 2012 \text { in } \\
\text { comparison } \\
\text { with other } \\
\text { banks }\end{array}$ & 60 & $\begin{array}{l}\text { Third place in } \\
\text { economic re- } \\
\text { sults in period } \\
2010-2012 \\
\text { in comparison } \\
\text { with other } \\
\text { banks }\end{array}$ & 40 & $\begin{array}{l}\text { The worth } \\
\text { economic } \\
\text { results in } \\
\text { period } 2010 \\
\text { - } 2012 \text { in } \\
\text { comparison } \\
\text { with other } \\
\text { banks }\end{array}$ \\
\hline $\begin{array}{l}\text { Approaches } \\
\text { to employees' } \\
\text { selection (B2) }\end{array}$ & 60 & $\begin{array}{l}\text { Sophisticated } \\
\text { approach to } \\
\text { the selection } \\
\text { of employ- } \\
\text { ees, but no } \\
\text { information } \\
\text { about specific } \\
\text { achievements }\end{array}$ & 60 & $\begin{array}{l}\text { Sophis- } \\
\text { ticated } \\
\text { approach to } \\
\text { the selection } \\
\text { of employ- } \\
\text { ees, but no } \\
\text { information } \\
\text { about spe- } \\
\text { cific achieve- } \\
\text { ments }\end{array}$ & 70 & $\begin{array}{l}\text { Sophisticated } \\
\text { approach to } \\
\text { the selection } \\
\text { of employ- } \\
\text { ees, but no } \\
\text { information } \\
\text { about specific } \\
\text { achievements; } \\
\text { winner of } \\
\text { Sodexo Em- } \\
\text { ployer of the } \\
\text { decade }\end{array}$ & 40 & $\begin{array}{l}\text { Unspecified } \\
\text { procedure } \\
\text { of selec- } \\
\text { tion and no } \\
\text { information } \\
\text { about specific } \\
\text { achievements }\end{array}$ \\
\hline $\begin{array}{l}\text { Approaches } \\
\text { to suppliers' } \\
\text { selection (B3) }\end{array}$ & 60 & $\begin{array}{l}\text { Only ČS has } \\
\text { a published } \\
\text { standardized } \\
\text { procedure } \\
\text { for suppliers' } \\
\text { selection; but } \\
\text { there are not } \\
\text { any results }\end{array}$ & 20 & $\begin{array}{l}\text { Only men- } \\
\text { tion about } \\
\text { cooperation } \\
\text { with ecologi- } \\
\text { cally minded } \\
\text { supplier }\end{array}$ & 40 & $\begin{array}{l}\text { Governed by } \\
\text { the principles } \\
\text { of Ethical } \\
\text { Souring Pol- } \\
\text { icy of Société } \\
\text { Générale; this } \\
\text { document is } \\
\text { not published }\end{array}$ & 10 & $\begin{array}{l}\text { For each busi- } \\
\text { ness partner } \\
\text { provides only } \\
\text { one docu- } \\
\text { ment about } \\
\text { the integrity. } \\
\text { There is no } \\
\text { more infor- } \\
\text { mation. }\end{array}$ \\
\hline $\begin{array}{l}\mathrm{B}=(\mathrm{B} 1+\mathrm{B} 2+\mathrm{B} 3) \\
/ 3\end{array}$ & & 67 & & 50 & & 57 & & 30 \\
\hline
\end{tabular}

Despite the financial crisis, banks in the Czech environment are relatively successful. It is reflecting on results such as a net profit in recent years and also a high level of the capital adequacy which proves the stability of the Czech banking sector. The most successful bank was Česká 
spořitelna that achieved an average annual profit of CZK 14,1 billion in recent years. Second most successful bank was ČSOB with its CZK 13,3 billion then Komerční banka with CZK 12,2 billion and GE Money Bank with CZK 4,2 billion. A criterion „Direct economic results“ includes also values of ROA, ROE and the capital adequacy. The aim of the scoring was primarily a comparison of economic results within observed group of four selected banks. There is noteworthy to mention interesting results of GE Money Bank which achieved the best average result of $\operatorname{ROA}(2,6 \%)$ within a comparison to other banks in evaluated years. In terms of capital adequacy GE Money Bank has even reached value of over $20 \%$ where banks have to maintain a minimum capital requirement of $8 \%$ accordance with Basel II. Excessive values of this indicator can lead to solve an economic efficiency of the bank.

Indirect economic effects on a community $(C)$

Indirect economic effects on a community represent investments in public welfare and public services development. The aim of these philanthropic activities is to support public projects and services on a voluntary basis without any profit's expectation.

Tab. 3 - Evaluation criteria in the area of indirect economic effects on the community. Source: own.

\begin{tabular}{|c|c|c|c|c|c|c|c|c|}
\hline Criterion & \multicolumn{2}{|c|}{ ČS } & \multicolumn{2}{|c|}{ ČSOB } & \multicolumn{2}{|c|}{ KB } & \multicolumn{2}{|c|}{ GE } \\
\hline $\begin{array}{l}\text { Effect of } \\
\text { investment on } \\
\text { a public benefit } \\
\text { (C1) }\end{array}$ & 80 & $\begin{array}{l}\text { The largest } \\
\text { number of } \\
\text { philanthropic } \\
\text { projects, regu- } \\
\text { larly ranked } \\
\text { in the TOP } \\
\text { Responsible } \\
\text { Company, has } \\
\text { own founda- } \\
\text { tion, regular } \\
\text { structured } \\
\text { reports of } \\
\text { investment are } \\
\text { missing }\end{array}$ & 70 & $\begin{array}{l}\text { Many phil- } \\
\text { anthropic } \\
\text { projects } \\
\text { regularly } \\
\text { ranked in } \\
\text { the TOP } \\
\text { Responsible } \\
\text { Company, } \\
\text { regular struc- } \\
\text { tured reports } \\
\text { of invest- } \\
\text { ment are } \\
\text { missing }\end{array}$ & 70 & $\begin{array}{l}\text { Many phil- } \\
\text { anthropic } \\
\text { projects, has } \\
\text { own founda- } \\
\text { tion, regular } \\
\text { structured } \\
\text { reports of } \\
\text { investment are } \\
\text { missing }\end{array}$ & 50 & $\begin{array}{l}\text { Some men- } \\
\text { tions about } \\
\text { philanthropic } \\
\text { projects in } \\
\text { annual report, } \\
\text { regular struc- } \\
\text { tured reports } \\
\text { of investment } \\
\text { are missing }\end{array}$ \\
\hline $\begin{array}{l}\text { Effect on the } \\
\text { development } \\
\text { of employment } \\
\text { (C2) }\end{array}$ & 40 & $\begin{array}{l}\text { Support of } \\
\text { entrepreneurs } \\
\text { (innovative } \\
\text { programs } \\
\text { INOVACE, } \\
\text { INOSTART), } \\
\text { no many } \\
\text { information } \\
\text { about them, } \\
\text { no results }\end{array}$ & 60 & $\begin{array}{l}\text { Support } \\
\text { of social } \\
\text { business } \\
\text { (sheltered } \\
\text { workshops), } \\
\text { regular } \\
\text { information } \\
\text { on website, } \\
\text { structures } \\
\text { reports of } \\
\text { investment } \\
\text { are missing }\end{array}$ & 50 & $\begin{array}{l}\text { Partner of the } \\
\text { project Business } \\
\text { project of the } \\
\text { year, struc- } \\
\text { tures reports } \\
\text { of investment } \\
\text { and results are } \\
\text { missing }\end{array}$ & 0 & $\begin{array}{l}\text { No } \\
\text { information }\end{array}$ \\
\hline
\end{tabular}




\begin{tabular}{|c|c|c|c|c|c|c|c|c|}
\hline $\begin{array}{l}\text { Effect on a dis- } \\
\text { semination of } \\
\text { education and } \\
\text { promotion of } \\
\text { education (C3) }\end{array}$ & 70 & $\begin{array}{l}\text { Support the } \\
\text { initiative of } \\
\text { the Dept Ad- } \\
\text { visory, partner } \\
\text { of TV series, } \\
\text { published } \\
\text { education } \\
\text { book about } \\
\text { financial is- } \\
\text { sue, structures } \\
\text { reports of } \\
\text { investment are } \\
\text { missing }\end{array}$ & 80 & $\begin{array}{l}\text { Has own } \\
\text { foundation } \\
\text { program } \\
\text { of educa- } \\
\text { tion, many } \\
\text { projects } \\
\text { supporting } \\
\text { financial } \\
\text { literacy, part- } \\
\text { ner of the } \\
\text { competition } \\
\text { Financial } \\
\text { literacy } \\
\text { oriented to } \\
\text { students, } \\
\text { structures } \\
\text { reports of } \\
\text { investment } \\
\text { are missing }\end{array}$ & 20 & $\begin{array}{l}\text { Support the } \\
\text { initiative of the } \\
\text { Dept Advisory, } \\
\text { no more infor- } \\
\text { mation }\end{array}$ & 60 & $\begin{array}{l}\text { Project sup- } \\
\text { porting finan- } \\
\text { cial literacy } \\
\text { of children } \\
\text { (Understand } \\
\text { money), regu- } \\
\text { lar information } \\
\text { on website, } \\
\text { structures } \\
\text { reports of } \\
\text { investment are } \\
\text { missing }\end{array}$ \\
\hline $\begin{array}{l}C=(C 1+C 2+C 3) \\
/ 3\end{array}$ & \multicolumn{2}{|l|}{63} & \multicolumn{2}{|l|}{70} & \multicolumn{2}{|l|}{47} & \multicolumn{2}{|l|}{37} \\
\hline
\end{tabular}

Česká spořitelna has the largest number of philanthropic projects and support of non-profit organizations and foundations. For its socially beneficial function, Česká spořitelna established Foundation of Česká spořitelna where total investments in projects (in 2012) was 16,5 million. Together with ČSOB, Česká spořitelna regularly ranked in the TOP Responsible Company within the category The Largest Corporate Donor. Česká spořitelna provided donations in the amount of CZK 164,1 million in the years 2009 to 2011 what represents the greatest amount between selected banks. According to a methodology of a nomination of TOP Responsible Company, ČSOB has provided an amount of CZK 112,8 million. However when we take a look on amounts of gains, we can realized that mentioned donations represent only relatively small proportion of banks ${ }^{6}$ profits over the examined period $(0,43 \%$ for Česká spořitelna; $0,28 \%$ for ČSOB). Komerční banka states that its contribution to community services were CZK 7,7 million through its Foundation in 2012. Within a corporate philanthropy, regular structured reports of investment and providing of funds are missing in annual reports and public available information.

The social responsibility

Human rights (D)

Ethical principles adopted in individual banks and their communications towards key stakeholders are the most intertwined in criteria of the third pillar of social responsibility. Human rights in an organizational environment are mainly linked to an employment legal relationships and working conditions. In this context the key document represents a code of ethics which is used by all of selected banks except one. Banks largely base their businesses on ethical principles because bank-client relationship is the alpha and omega of their economic performance.

A highly discussed topic in the Czech Republic and abroad is related to equal opportunities where the issue of employment conditions for men and women is most commonly stated. However in the Czech banking sector, this question may not be considered as a problematic one 
because most of the employees in banks are women. The question is to what extent are women occupied in managerial positions. However banks expressed themselves with a very friendly attitude on this theme in their materials.

Tab. 4 - Evaluation criteria in the area of the Human rights. Source: own.

\begin{tabular}{|c|c|c|c|c|c|c|c|c|}
\hline Criterion & \multicolumn{2}{|r|}{ Čs } & \multicolumn{2}{|r|}{$\check{C} \mathrm{CSOB}$} & \multicolumn{2}{|r|}{$\mathrm{KB}$} & \multicolumn{2}{|r|}{ GE } \\
\hline $\begin{array}{l}\text { Code of Ethics } \\
\text { (D1) }\end{array}$ & 100 & $\begin{array}{c}\text { Internal } \\
\text { Code of } \\
\text { Ethics }\end{array}$ & 100 & $\begin{array}{l}\text { Internal } \\
\text { Code of } \\
\text { Ethics }\end{array}$ & 100 & $\begin{array}{c}\text { Internal } \\
\text { Code of } \\
\text { Ethics }\end{array}$ & 50 & $\begin{array}{l}\text { Taken Code } \\
\text { of Ethics } \\
\text { published by } \\
\text { the Czech } \\
\text { Banking As- } \\
\text { sociation }\end{array}$ \\
\hline $\begin{array}{c}\text { Anti- } \\
\text { discrimination } \\
\text { and equal } \\
\text { opportunities (D2) }\end{array}$ & 60 & $\begin{array}{l}\text { Mention } \\
\text { about } \\
\text { responsible } \\
\text { approach to } \\
\text { equal op- } \\
\text { portunities, } \\
\text { established } \\
\text { the anti-dis- } \\
\text { crimination } \\
\text { clause, no } \\
\text { more infor- } \\
\text { mation }\end{array}$ & 40 & $\begin{array}{l}\text { Mention } \\
\text { about } \\
\text { responsible } \\
\text { approach to } \\
\text { equal op- } \\
\text { portunities, } \\
\text { Program for } \\
\text { mothers and } \\
\text { fathers, no } \\
\text { more infor- } \\
\text { mation }\end{array}$ & 40 & $\begin{array}{c}\text { Mention } \\
\text { about } \\
\text { responsible } \\
\text { approach to } \\
\text { equal oppor- } \\
\text { tunities, Pro- } \\
\text { gram Talent } \\
\text { Management, } \\
\text { no more } \\
\text { information }\end{array}$ & 30 & $\begin{array}{l}\text { Mention } \\
\text { about } \\
\text { responsible } \\
\text { approach } \\
\text { to equal } \\
\text { opportuni- } \\
\text { ties, no more } \\
\text { information }\end{array}$ \\
\hline $\begin{array}{l}\text { Evidence of } \\
\text { incidents and } \\
\text { complaints on the } \\
\text { area of Human } \\
\text { rights (D3) }\end{array}$ & 50 & $\begin{array}{l}\text { Support of } \\
\text { institute of } \\
\text { Ombudsman, } \\
\text { established } \\
\text { the company } \\
\text { position of } \\
\text { Manager for } \\
\text { ethics }\end{array}$ & 10 & $\begin{array}{l}\text { Only men- } \\
\text { tion about it } \\
\text { but no more } \\
\text { information }\end{array}$ & 40 & $\begin{array}{l}\text { Support of } \\
\text { institute of } \\
\text { Ombuds- } \\
\text { man (more } \\
\text { information } \\
\text { about it than } \\
\text { in GE), no } \\
\text { more infor- } \\
\text { mation }\end{array}$ & 30 & $\begin{array}{c}\text { Support of } \\
\text { institute of } \\
\text { Ombudsman, } \\
\text { no more } \\
\text { informa- } \\
\text { tion (less } \\
\text { information } \\
\text { about it than } \\
\text { in } \mathrm{KB} \text { ) }\end{array}$ \\
\hline $\mathrm{D}=(\mathrm{D} 1+\mathrm{D} 2+\mathrm{D} 3) / 3$ & & 70 & & 50 & & 60 & & 37 \\
\hline
\end{tabular}

Within the criterion of Code of Ethics, only existence of this key document in the bank has been evaluated not document's quality or compliance. A compliance of the Code of Ethics should represent an essential precondition for socially responsible behavior of banks but information about compliance or non-compliance with ethical standards are not available and banks can also rely on subjective opinions and individual cases of dissatisfied clients or employees. GE Money Banks is committed to the Code of Ethics issued by the Czech Banking Association without publishing any internal code of ethics.

\section{Social policy (E)}

The social policy is largely intertwined with already evaluated criteria. Banks are often involved to a public life of a community by the means of their employees and their volunteer activities. Banks count on a benefit of such charitable projects and activities, especially in relation to a posi- 
tive perception of banks in public eyes. An adoption of anti-corruption policies and procedures are an integral part of socially responsible principles in an organization. A corruption has relatively strong fundamentals in a historical context of the Czech Republic. Therefore companies are exposed to a social pressure to adopt standardized and systematic anti-corrupt practices.

Tab. 5 - Evaluation criteria in the area of the Social policy. Source: own.

\begin{tabular}{|c|c|c|c|c|c|c|c|c|}
\hline Criterion & \multicolumn{2}{|r|}{ ČS } & \multicolumn{2}{|r|}{$\check{C} \mathrm{SOB}$} & \multicolumn{2}{|r|}{$\mathrm{KB}$} & \multicolumn{2}{|r|}{ GE } \\
\hline $\begin{array}{l}\text { Effect of activities } \\
\text { and participation } \\
\text { in public life of a } \\
\text { community (E1) }\end{array}$ & 70 & $\begin{array}{c}\text { Volunteer } \\
\text { program } \\
\text { Managers for } \\
\text { good things } \\
\text { (cooperation } \\
\text { with non- } \\
\text { profit or- } \\
\text { ganizations), } \\
\text { no more } \\
\text { information } \\
\text { about results }\end{array}$ & 60 & $\begin{array}{l}\text { Volunteer } \\
\text { program } \\
\text { Helping } \\
\text { Together } \\
\text { (coop- } \\
\text { eration with } \\
\text { non-profit } \\
\text { organiza- } \\
\text { tions) - less } \\
\text { information } \\
\text { in com- } \\
\text { parison with } \\
\text { ČS, no more } \\
\text { informa- } \\
\text { tion about } \\
\text { results }\end{array}$ & 40 & $\begin{array}{l}\text { Annual blood } \\
\text { donation, } \\
\text { financial sup- } \\
\text { port of ama- } \\
\text { teur sports, } \\
\text { no more } \\
\text { information }\end{array}$ & 70 & $\begin{array}{c}\text { Founded } \\
\text { a separate } \\
\text { organization } \\
\text { GE Volun- } \\
\text { teers, Project } \\
\text { GE Health, } \\
\text { no more } \\
\text { information } \\
\text { about results }\end{array}$ \\
\hline $\begin{array}{l}\text { Anti-corruption } \\
\text { policies and proce- } \\
\text { dures (E2) }\end{array}$ & 10 & $\begin{array}{l}\text { Only men- } \\
\text { tion about it }\end{array}$ & 60 & $\begin{array}{l}\text { Adoption } \\
\text { of policy } \\
\text { KBC Group } \\
\text { against Cor- } \\
\text { ruption and } \\
\text { Bribery, no } \\
\text { informa- } \\
\text { tion about } \\
\text { results }\end{array}$ & 70 & $\begin{array}{l}\text { Application } \\
\text { of Anti- } \\
\text { corruption } \\
\text { policy (avail- } \\
\text { able at its } \\
\text { website), no } \\
\text { information } \\
\text { about results }\end{array}$ & 0 & $\begin{array}{c}\text { No } \\
\text { information }\end{array}$ \\
\hline $\mathrm{E}=(\mathrm{E} 1+\mathrm{E} 2) / 2$ & & 40 & & 60 & & 55 & & 35 \\
\hline
\end{tabular}

Employees of all banks can use one or two days in a year on a charitable activities besides a statutory number of vacation days. In all monitored banks a very high level of employees' involvement has been showed. The possibility to voluntarily participate in more than 130 non-profit organizations has used by a total of 1,805 employees of Česká spořitelna (that is about $8 \%$ more than in 2010). In addition within a program „Managers for good things“, Česká spořitelna offer its employees in a leadership position sharing expertise with some non-profit organization for a period of one week. Over 500 employees in 48 non-profit organizations have participated in a volunteer program of ČSOB called „Helping Together“. Employees of Komerční banka participate in blood donation every year. Several award-winning independent organization GE Volunteers is a very good advantage and basement for a good scoring of GE Money Bank. In 2012, GE Money Bank managed to get involved 658 volunteers in 124 volunteer events. Volunteers from GE Volunteers are recruited from among employees but also their family members and friends. In the project GE Health, GE Money Bank is also trying to inform the public about an importance of 
healthy eating and organizes seminars about stress management, disease prevention and tobacco issue. Top of a project is a GE week for health organization.

\section{Employment (F)}

A hallmark of a good employer represents a very important aspect of their business for banks. Properly motivated and satisfied employee is particularly very much appreciated in the banking business. Motivation and development programs are widely used by all selected banks. Differences can be founded only in a particular specialization of individual programs. Also noteworthy is the support for departing employees so called outplacement.

Tab. 6 - Evaluation criteria in the area of the Employment. Source: own.

\begin{tabular}{|c|c|c|c|c|c|c|c|c|}
\hline Criterion & \multicolumn{2}{|r|}{ ČS } & \multicolumn{2}{|r|}{ ČSOB } & \multicolumn{2}{|r|}{$\mathrm{KB}$} & \multicolumn{2}{|r|}{ GE } \\
\hline $\begin{array}{l}\text { Motivation } \\
\text { programs and } \\
\text { benefits (F1) }\end{array}$ & 40 & $\begin{array}{l}\text { Wide range } \\
\text { of benefits }\end{array}$ & 30 & $\begin{array}{c}\text { Wide range } \\
\text { of benefits } \\
\text { - worse } \\
\text { described in } \\
\text { comparison } \\
\text { with CS and } \\
\text { KB }\end{array}$ & 40 & $\begin{array}{l}\text { Wide range } \\
\text { of benefits }\end{array}$ & 30 & $\begin{array}{c}\text { Wide range } \\
\text { of ben- } \\
\text { efits - worse } \\
\text { described in } \\
\text { comparison } \\
\text { with Č and } \\
\text { KB }\end{array}$ \\
\hline $\begin{array}{c}\text { System of } \\
\text { employee } \\
\text { education and } \\
\text { development (F2) }\end{array}$ & 50 & $\begin{array}{l}\text { Language } \\
\text { lessons, } \\
\text { mentoring, } \\
\text { coaching, } \\
\text { development } \\
\text { centum for } \\
\text { managers, } \\
\text { participation } \\
\text { in trainee } \\
\text { program } \\
\text { Group Junior } \\
\text { Achievement } \\
\text { for graduates }\end{array}$ & 50 & $\begin{array}{c}\text { Many } \\
\text { educational } \\
\text { courses, } \\
\text { which are } \\
\text { detailed } \\
\text { described } \\
\text { on website }\end{array}$ & 40 & $\begin{array}{c}\text { Project } \\
\text { Talent } \\
\text { management, } \\
\text { M'Academy } \\
\text { (development } \\
\text { of managerial } \\
\text { skills) with- } \\
\text { out detailed } \\
\text { description }\end{array}$ & 40 & $\begin{array}{l}\text { Leadership } \\
\text { programs, } \\
\text { GE Money } \\
\text { Univer- } \\
\text { sity without } \\
\text { detailed } \\
\text { description }\end{array}$ \\
\hline $\begin{array}{l}\text { System for dealing } \\
\text { with complaints } \\
\text { of employees (F3) }\end{array}$ & 80 & $\begin{array}{l}\text { Sophisticated } \\
\text { system for } \\
\text { dealing with } \\
\text { employee } \\
\text { complaints } \\
\text { and feedback }\end{array}$ & 0 & $\begin{array}{l}\text { No } \\
\text { information }\end{array}$ & 30 & $\begin{array}{c}\text { Regular } \\
\text { employee } \\
\text { satisfaction } \\
\text { survey (more } \\
\text { information } \\
\text { in com- } \\
\text { parison with } \\
\text { GE), without } \\
\text { any results } \\
\text { and specifica- } \\
\text { tion how } \\
\text { to measure } \\
\text { satisfaction }\end{array}$ & 20 & $\begin{array}{c}\text { Regular } \\
\text { employee } \\
\text { satisfaction } \\
\text { survey (more } \\
\text { information } \\
\text { in com- } \\
\text { parison with } \\
\text { GE), without } \\
\text { any results } \\
\text { and specifi- } \\
\text { cation how } \\
\text { to measure } \\
\text { satisfaction }\end{array}$ \\
\hline $\begin{array}{l}\text { Staff turnover } \\
\text { (F4) }\end{array}$ & 0 & $\begin{array}{l}\text { No } \\
\text { information }\end{array}$ & 0 & $\begin{array}{l}\text { No } \\
\text { information }\end{array}$ & 0 & $\begin{array}{l}\text { No } \\
\text { information }\end{array}$ & 0 & $\begin{array}{l}\text { No } \\
\text { information }\end{array}$ \\
\hline
\end{tabular}




\begin{tabular}{|c|c|c|c|c|c|c|c|c|}
\hline $\begin{array}{l}\text { Support for de- } \\
\text { parting employees } \\
\text { (F5) }\end{array}$ & 40 & $\begin{array}{c}\text { Active } \\
\text { consultation } \\
\text { service to } \\
\text { find a new } \\
\text { job, seminar } \\
\text { and inter- } \\
\text { views with } \\
\text { departing } \\
\text { employees, } \\
\text { no informa- } \\
\text { tion about } \\
\text { results }\end{array}$ & 40 & $\begin{array}{c}\text { Active } \\
\text { consultation } \\
\text { service to } \\
\text { find a new } \\
\text { job, seminar } \\
\text { and inter- } \\
\text { views with } \\
\text { departing } \\
\text { employees, } \\
\text { no informa- } \\
\text { tion about } \\
\text { results }\end{array}$ & 0 & $\begin{array}{l}\text { No } \\
\text { information }\end{array}$ & 0 & $\begin{array}{c}\text { No } \\
\text { information }\end{array}$ \\
\hline $\begin{aligned} \mathrm{F} & =(\mathrm{F} 1+\mathrm{F} 2+\mathrm{F} 3 \\
& +\mathrm{F} 4+\mathrm{F} 5) / 5\end{aligned}$ & & 42 & & 24 & & 22 & & 18 \\
\hline
\end{tabular}

In terms of motivation programs and employees' benefits it can be stated that employees of banks have very good position in domestic conditions. In addition to traditional benefits (such as luncheon voucher, a supplementary pension, a life insurance, contributions to a recreation, favorable conditions for a purchase of bank's products etc.) banks offer aforementioned days off for volunteer activities and event programs. Banks do not publish a specific wording of these motivation programs anywhere therefore a rating of all monitored banks is so low in this criterion. Also an average rate of staff turnover is not stated in banks' materials.

\section{Consumer protection $(G)$}

In this context, the most important criterion is a monitoring and measuring customers' satisfaction. As has been mentioned several times before, customers' satisfaction has a greatest impact on banks' business, but results of this criterion devoid of any exact data because banks are monitoring and measuring customers' satisfaction only for internal needs.

Tab 7 - Evaluation criteria in the area of the Consumer protection. Source: own.

\begin{tabular}{|c|c|c|c|c|c|c|c|c|}
\hline Criterion & \multicolumn{2}{|r|}{ ČS } & \multicolumn{2}{|r|}{ ČSOB } & \multicolumn{2}{|r|}{$\mathrm{KB}$} & \multicolumn{2}{|r|}{ GE } \\
\hline $\begin{array}{c}\text { Compliance with } \\
\text { laws in marketing } \\
\text { communication } \\
\text { (G1) }\end{array}$ & 50 & $\begin{array}{l}\text { It is assumed } \\
\text { that bank } \\
\text { cannot af- } \\
\text { ford to have } \\
\text { an illegal } \\
\text { advertising } \\
\text { due to a size } \\
\text { of bank and } \\
\text { possible legal } \\
\text { sanctions }\end{array}$ & 50 & $\begin{array}{c}\text { It is as- } \\
\text { sumed that } \\
\text { bank cannot } \\
\text { afford to } \\
\text { have an ille- } \\
\text { gal advertis- } \\
\text { ing due to a } \\
\text { size of bank } \\
\text { and possible } \\
\text { legal sanc- } \\
\text { tions }\end{array}$ & 50 & $\begin{array}{l}\text { It is assumed } \\
\text { that bank } \\
\text { cannot af- } \\
\text { ford to have } \\
\text { an illegal } \\
\text { advertising } \\
\text { due to a size } \\
\text { of bank and } \\
\text { possible legal } \\
\text { sanctions }\end{array}$ & 50 & $\begin{array}{l}\text { It is assumed } \\
\text { that bank } \\
\text { cannot af- } \\
\text { ford to have } \\
\text { an illegal } \\
\text { advertising } \\
\text { due to a size } \\
\text { of bank and } \\
\text { possible legal } \\
\text { sanctions }\end{array}$ \\
\hline
\end{tabular}




\begin{tabular}{|c|c|c|c|c|c|c|c|c|}
\hline $\begin{array}{l}\text { Monitoring and } \\
\text { measuring of cus- } \\
\text { tomer's satisfaction } \\
\text { (G2) }\end{array}$ & 50 & $\begin{array}{l}\text { Monitoring } \\
\text { of customer's } \\
\text { satisfaction } \\
\text { for internal } \\
\text { purposes, } \\
\text { published } \\
\text { only areas of } \\
\text { survey and } \\
\text { total result } \\
(93 \%)\end{array}$ & 30 & $\begin{array}{l}\text { Monitor- } \\
\text { ing of } \\
\text { customer's } \\
\text { satisfaction } \\
\text { for internal } \\
\text { purposes } \\
\text { - published } \\
\text { only areas of } \\
\text { survey }\end{array}$ & 10 & $\begin{array}{l}\text { Monitoring } \\
\text { of customer's } \\
\text { satisfaction } \\
\text { for internal } \\
\text { purposes } \\
\text { - without any } \\
\text { other infor- } \\
\text { mation }\end{array}$ & 10 & $\begin{array}{l}\text { Monitoring } \\
\text { of customer's } \\
\text { satisfaction } \\
\text { for internal } \\
\text { purposes } \\
\text {-without any } \\
\text { other infor- } \\
\text { mation }\end{array}$ \\
\hline $\begin{array}{c}\text { Customer Com- } \\
\text { plaints (G3) }\end{array}$ & 60 & $\begin{array}{l}\text { Bank informs } \\
\text { about } 80 \% \\
\text { success rate } \\
\text { to resolve a } \\
\text { complaint to } \\
\text { a next day }\end{array}$ & 30 & $\begin{array}{c}\text { Only } \\
\text { general } \\
\text { informa- } \\
\text { tion about } \\
\text { possibilities } \\
\text { to file a } \\
\text { complaint }\end{array}$ & 80 & $\begin{array}{l}\text { An elaborate } \\
\text { system of } \\
\text { submission } \\
\text { of complaints } \\
\text { with three } \\
\text { instances }\end{array}$ & 30 & $\begin{array}{l}\text { Only general } \\
\text { information } \\
\text { about possi- } \\
\text { bilities to file } \\
\text { a complaint }\end{array}$ \\
\hline $\mathrm{G}=(\mathrm{G} 1+\mathrm{G} 2+\mathrm{G} 3) / 3$ & & 53 & & 37 & & 47 & & 30 \\
\hline
\end{tabular}

A complete absence of data was recorded in the criterion of marketing communication and compliance with it. If banks are trying to present themselves in a term of a social ethics, they should appropriately informed about it general public and banks' stakeholders. It is assumed that banks cannot afford to have an illegal advertising due to a size of banks and possible legal sanctions therefore all selected banks received fifty points in first criterion. At zero evaluation results would distort the scoring throughout the area, as well as at hundred point evaluation.

Customers' satisfaction is mostly monitored and measured internally but again without any publicly available results. For example, Česká spořitelna informs that results are based very well which is based on employees' satisfaction survey and which are compared to an European average and they manage to improve internal processes and services. In its annual report, bank presents only a result of measuring a satisfaction of corporate clients with $93 \%$ satisfaction. To increase the objectivity of CSR reporting, it would be very beneficial comprehensive publication of results of satisfaction measuring and forms of a measurement. According to a PwC study in 2010, exactly the same bank (Česká spořitelna) achieved the best score among surveyed banks with a result of 4,06 points on a scale from 0 to 5 . Komerční banka was on a second place with 3,99, ČSOB with 3,97 and GE Money Bank with 3,95. A study was conducted with the use of mystery shopping. Rating was related to an exposure of a brand and its value on a customer (Brand), communication with customers (Communication), surrounding acting on a customer (Environment), methods of products' offering (Offering) and approach to dealing with a customer (Culture).

Last rated social criterion relates to complaints and their manner of administration from clients towards a bank. Komerční banka has an elaborate system of submission of complaints with three instances. After first two instances which represent reporting of complaints with a phone or e-mail and transferring of complaint to a department of Complaint management, clients can use ombudsman's services. In this context supporting document of the Ombudsman institution is called the Ombudsman Charter which is focused on clients' complaints and is available on the website of a bank. In 2012, 119 clients contacted an Ombudsman and the Ombudsman was directly resolved 21 cases. Česká spořitelna informs about $80 \%$ success rate to resolve a complaint to a next day. 
According to the annual report, team of the Ombudsman resolves complaints for an average of 11 days with a satisfaction of $75 \%$ with a solution. It is also objectively stated that subjects of complaints are often failures of individual workers. GE Money Bank and ČSOB provide only general information about possibilities to file a complaint.

\section{Environment}

Environmental policy $(H)$

An environmental policy and issues related to an environmental protection are considered as an important part of CSR concept by commercial banks. Banks as well as companies from other sectors of the economy have to adopt environmental policies and principles for a functioning of socially responsible organizations in regard to a sustainable growth and pressures from public. An environmental policy does not play an important role due to an economic performance of commercial banks but banks still give quite a lot of financial resources in an environmental matter especially in a form of financing of environmentally focused projects.

Tab. 8 - Evaluation criteria in the area of the Environmental policy. Source: own.

\begin{tabular}{|c|c|c|c|c|c|c|c|c|}
\hline Criterion & \multicolumn{2}{|r|}{ ČS } & \multicolumn{2}{|r|}{ ČSOB } & \multicolumn{2}{|r|}{$\mathrm{KB}$} & \multicolumn{2}{|r|}{ GE } \\
\hline $\begin{array}{c}\text { Voluntary } \\
\text { instruments } \\
\text { (H1) }\end{array}$ & 80 & $\begin{array}{l}\text { Presentation } \\
\text { of envi- } \\
\text { ronmental } \\
\text { projects and } \\
\text { results }\end{array}$ & 60 & $\begin{array}{c}\text { Presenta- } \\
\text { tion of } \\
\text { environmental } \\
\text { projects but } \\
\text { without de- } \\
\text { tailed results }\end{array}$ & 70 & $\begin{array}{l}\text { Commitment } \\
\text { to take } 100 \% \text { of } \\
\text { green energy }\end{array}$ & 30 & $\begin{array}{l}\text { Not much } \\
\text { informa- } \\
\text { tion about } \\
\text { environ- } \\
\text { mental } \\
\text { projects }\end{array}$ \\
\hline $\begin{array}{l}\text { Environmental } \\
\text { impacts of an } \\
\text { activity (H2) }\end{array}$ & 80 & $\begin{array}{c}\text { A lot of } \\
\text { informa- } \\
\text { tion about } \\
\text { investment to } \\
\text { ecology, own } \\
\text { Energy team }\end{array}$ & 60 & $\begin{array}{l}\text { Committed } \\
\text { to comply- } \\
\text { ing with } \\
\text { international } \\
\text { rules of the } \\
\text { World Banks } \\
\text { called Equator } \\
\text { Principles, } \\
\text { no detailed } \\
\text { figures }\end{array}$ & 60 & $\begin{array}{l}\text { Committed to } \\
\text { complying with } \\
\text { international } \\
\text { rules of the } \\
\text { World Banks } \\
\text { called Equator } \\
\text { Principles, no } \\
\text { detailed figures }\end{array}$ & 50 & $\begin{array}{l}\text { Environ- } \\
\text { mental } \\
\text { projects } \\
\text { but not } \\
\text { too much } \\
\text { informa- } \\
\text { tion }\end{array}$ \\
\hline $\mathrm{H}=(\mathrm{H} 1+\mathrm{H} 2) / 2$ & & 80 & & 60 & & 65 & & 40 \\
\hline
\end{tabular}

In terms of an environmental policy, banks generally agree to reduce a consumption of energy and resources in their programs and try to prove it by concrete results. For example, Česká spořitelna recorded a decline in a consumption of printed papers by $13 \%$ in relation to commitments to reduce consumption. ČSOB highlights as reducing energy consumption so reducing fuel consumption related with business trips and it is very proud of a headquarter building which was several times awarded for its friendly approach to an environment. Komerční banka also states that it has been committed to take $100 \%$ of green energy, i.e. energy which is produced from renewable sources. In both environmental criteria GE Money Banks is lagging because informs very little about environmental policies in its resources.

Significantly more important resource related with environmental policy and protection lies in an approach to finance environmental projects of banks. Česká spořitelna has the best prereq- 
uisites to support these projects particularly by the means of its special Energy team ČS. Team members assist potential investors with a preparation and implementation of energy projects in the field of energy savings and energy production from renewable sources. There were financed projects for nearly CZK 5 billion in 2011. ČSOB and Komerční banka are committed to complying with international rules of the World Banks called Equator Principles. According to these rules, banking sector identify and manage social and environmental risks in a project financing. Banks have also promoted and offered products associated with a government suspended project called Green Savings but with exception of GE Money Bank which this possibility has not stated. Available information is missing data about specific numbers and amounts invested in environmental projects. Only Česká spořitelna provides numbers and amounts of investment projects about production of energy from renewable sources.

Summary of Results

Scoring of individual areas represents an average of all evaluated criteria in the given area. It was evaluated 8 areas containing 26 criteria in total.

Tab. 9 - Summary of results according to evaluated areas. Source: own.

\begin{tabular}{|l|c|c|c|c|c|c|}
\hline \multicolumn{1}{|c|}{ Areas } & $\begin{array}{c}\text { ČS } \\
\text { points }\end{array}$ & $\begin{array}{c}\text { ČSOB } \\
\text { points }\end{array}$ & $\begin{array}{c}\text { KB } \\
\text { points }\end{array}$ & $\begin{array}{c}\text { GE } \\
\text { points }\end{array}$ & $\begin{array}{c}\text { Average } \\
\text { points }\end{array}$ & $\begin{array}{c}\text { Standard } \\
\text { deviation }\end{array}$ \\
\hline Management CSR & 54 & 42 & 34 & 8 & 35 & 19.490 \\
\hline $\begin{array}{l}\text { Direct economic impacts on } \\
\text { a community }\end{array}$ & 67 & 50 & 57 & 30 & 51 & 15.649 \\
\hline $\begin{array}{l}\text { Indirect economic impacts } \\
\text { on a community }\end{array}$ & 63 & 70 & 47 & 37 & 54 & 14.998 \\
\hline Human rights & 70 & 50 & 60 & 37 & 54 & 14.100 \\
\hline Social policy & 40 & 60 & 55 & 35 & 48 & 11.900 \\
\hline Employment & 42 & 24 & 22 & 18 & 27 & 10.630 \\
\hline Consumer protection & 53 & 37 & 47 & 30 & 42 & 10.240 \\
\hline Environmental policy & 80 & 60 & 65 & 40 & 61 & 16.520 \\
\hline Standard deviation - banks & 13.897 & 14.650 & 14.320 & 11.010 & - & - \\
\hline $\begin{array}{l}\text { CSR index }= \\
\text { (A+B+C+D+E+F+G+H)/8 }\end{array}$ & $\mathbf{5 9}$ & $\mathbf{4 9}$ & $\mathbf{4 8}$ & $\mathbf{2 9}$ & $\mathbf{4 6}$ & - \\
\hline
\end{tabular}

Based on results in a summary table it can be noted that a value of CSR index of selected bank is ranged at an average level. The best results achieved Česká spořitelna (average value of achieved points per evaluated area was 59) and the worst rating was given to GE Money Bank (an average value was only 29 points). A table shows that CSR index values of GE Money Bank are more homogeneous than of other banks that a value of standard deviation has confirmed.

Česká spořitelna achieved the highest scoring in all three pillars. The poorest result of selected banks was reached by GE Money Bank. It should be noted that GE Money Bank is not as big as other three banks in term of number of clients, employees and an amount of profit. ČSOB 
and Komerční banka achieved very similar results in all evaluated areas and their level of social responsibility can be rated as a solid one.

Differences in individual areas of CSR have been quantified by a standard deviation. The biggest differences in a scoring were observed in an area of the CSR Management and the Environmental policy. The employment area and the Consumer Protection were the most homogeneous across all surveyed banks.

The data were subjected to Cluster analysis. Purpose was to determine the similarity of the evaluated areas. For Cluster analysis we used the program R (R Core Team, 2013).

We used hierarchical clustering and for distance measurement was chosen Euclidean distance. The output of a hierarchical clustering is a dendogram of similarity. The dendogram shows the distance of each score selected areas and allows to identify clusters with the biggest similarity.

\section{Dendrogram of agnes $(x=d i)$}

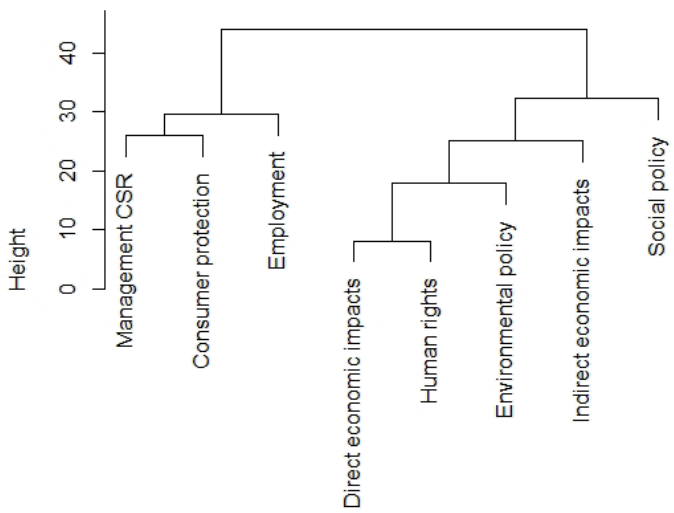

Agglomerative Coefficient $=0.51$

Fig. 1 - Dendogram of similarity. Source: own.

Cluster analysis identified two main clusters (groups), which are characterized by considerable similarity of responses. The first group includes the area of CSR Management, Consumer protection and Employment. The second group consists of the area of Direct economic impacts, Human rights, Environmental policy, Indirect economic impacts and Social policy. Agglomerative coefficient reached 0,51 , which indicates that objects are very similar.

The results were subjected to Analysis of Heatmap, which shows similarities within the different areas across selected banks.

Based on this analysis, we can say, for example, that the structure of Employment area is very similar in all of the selected banks (most between ČSOB and KB). Another example might be the structure of Direct economic impacts, which is similar in ČSOB and GE Money Bank. Conversely, the biggest difference can be seen in Social policy area of ČS in compared to other banks. 
In the Heatmap clusters are shown across banks and simultaneously across groups of answers.

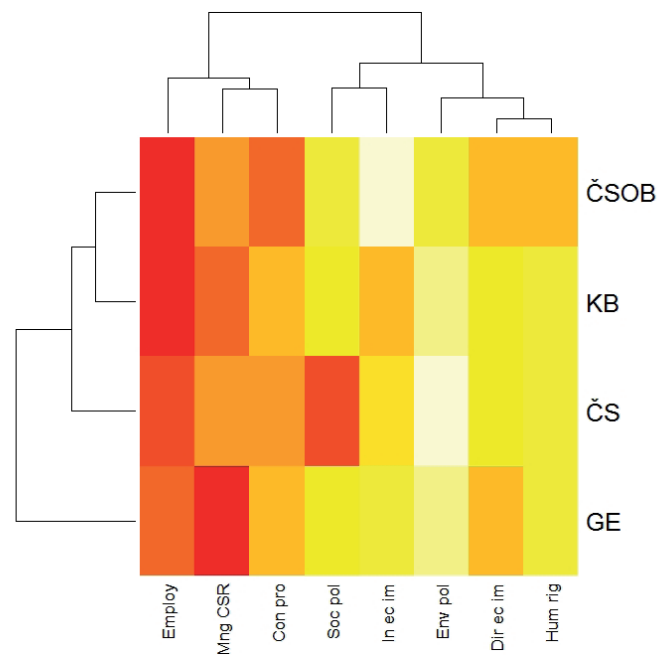

Fig. 2 - Heatmap clusters. Source: own.

\section{CONCLUSION}

Concepts of corporate social responsibility and their ethical behavior in business area are no new but they are becoming extremely topical because crisis significantly highlighted the need for integration of moral principles in a banking business.

Knowledge of business practices indicate to a fact that the acceptance of moral principles in business is not integrated into a management decisions of companies and it cannot be expected that self-regulatory ethical instruments of companies (such as CSR) will be effective.

The experience with CSR application and ethical principles in the banking sector tend to accept the opinion that the social responsibility of banks and baking ethics are seen by a bank management as a suitable marketing tools for communication with a general public and are not integrated into policies of commercial banks. Even experience with crisis demonstrated the fact that there is an absence of moral principles in decision making of bank managers.

Set aim of this article was met. CSR index level in selected Czech banks was ranged in the interval from 29 to 59 points. In this research, best results in the CSR area achieved Česká spořitelna with an average rating of 59 points than ČSOB with 49 points, than Komerční banka with 48 points and last but not least GE Money Bank with 29 points.

Cluster analysis identified two main clusters (groups), which are characterized by considerable similarity of responses. The first group includes the area of CSR Management, Consumer protection and Employment. The second group consists of the area of Direct economic impacts, Human rights, Environmental policy, Indirect economic impacts and Social policy. Agglomerative coefficient reached 0,51 , which indicates that objects are very similar. 
From a broader perspective it can be stated that banks want to present themselves in the best possible way which suppresses any ability of reflection and ability to publish negative impacts of their activities. An evidence of this behavior is the fact that banks do not provide any information about results of employees' and customers' satisfaction research and related information about staff turnover rate. Publication of negative results of banks' activities may paradoxically lead to more objectivity in reporting of CSR activities. Furthermore, banks could also indicate possible areas for improvement and commit themselves to the axles.

\section{Acknowledgement:}

This paper was created at Tomas Bata University in Zlin and was supported by Project No. IGA/FaME/2013/010: Satisfaction mirror effect and bank financial performance.

\section{References}

1. Belás, J. (2010). Management komerčných bánk, bankových obchodov a operácií. Žilina: Georg.

2. Classon, J., \& Dahlstrőm, J. (2006). How can CSR affect company performance. A qualitative study od CSR and its effects. Karlstads Universität: Business Administration Master Thesis.

3. Fassin, Y., \& Gosselin, D. (2011). The Collapse of a European Bank in the Financial Crisis: An Analysis from Stakeholder and Ethical Perspectives. Journal of Business Ethics, 102(2), 169-191.

4. Graafland, J., J., \& Van De Ven, B. W. (2011). The Credit Crisis and the Moral Responsibility of Professionals in Finance. Journal of Business Ethics, 103(4), 605-619.

5. Gibbons, D. (2011). Held to account: a review of Corporate Social Responsibility in retail banking from the consumerperspective. London: Centre for Responsible Credit.

6. Goss, A., Gordon S., \& Roberts, G. S. (2011). The Impact of Corporate Social Responsibility on the Cost of Bank Loans. Journal of Banking \& Finance, 35(7), 1794-1810. http://dx.doi.org/10.1016/j.jbankfin.2010.12.002

7. Chatterjee, CH., \& Lefcovitch, A. (2009). Corporate social responsibility and banks. Amicus Curiae, 2009(78), 24-28.

8. Chih, H.L., Chih, H.H., \& Chen, T.Y. (2010). On the Determinants of Corporate Social Responsibility: International Evidence on the Financial Industry. Journal of Business Ethics, 93(1), 115-135. http://dx.doi.org/10.1007/s10551-009-0186-x

9. Icke, B., T., Caliscan, E. N., Ayturk, Y., \& Icke, M. A. (2011). An Empirical Research of Ethical Banking in Turkey. Journal of Modern Accounting and Auditing, 7(3), 289-304.

10. McDonald, L., \& Rundle-Thiele, S. (2008). Corporate social responsibility a bank customer safisfaction. International Journal of Bank Marketing, 26(3), 170-182. http://dx.doi.org/10.1108/ 02652320810864643

11. Mejstř́k, M., Pečená, M., \& Teplý, P. (2008). Základníprincipy bankovnictví. Praha: Karolinum.

12. Palomino, P. R., \& Martinez, R. (2011). Human resource management and ethical behaviour: Exploring in the spanish banking industry. Ramon Llull Journal of Applied Ethics, 1(2), 69-88. 
13. Paulet, E. (2011) Banking ethics. Corporate Governance, 11(3), 293-300. http://dx.doi. org/10.1108/14720701111138715

14. Pérez, A., \& Del Bosque, I. R. (2012). The Role of CSR in the Corporate Identity of Banking Service Providers. Journal of Business Ethics, 108(2), 145-166. http://dx.doi. org/10.1007/s10551-011-1067-7

15. Plášková, A. (2009). Společenská odpovédnost firem (CSR): Aplikace a bodnocení podnikatelský sektor. Praha: Národní informační středisko podpory kvality.

16. Rendtorff, J., D., \& Mattsson, J. (2012). Ethics in the bank internet encounter: an explorative study. Journal of Information, Communication and Ethics in Society, 10(1), 36-51. http:// dx.doi.org/10.1108/14779961211210649

17. Robin, D. (2008). Toward an Applied Meaning for Ethics in Business. Journal of Business Ethics, 89(1), 139-150.

18. R Core Team (2013). R: A language and environment for statistical computing. $\mathrm{R}$ Foundation for Statistical Computing, Vienna, Austria. Retrieved from: http://www.Rproject.org/

19. San-Jose, L., Retolaza, J. L., \& Gutierre-Goiria, J. (2011). Are Ethical Banks Different? A comparative analysis using Radical Afffinity Index. Journal of Business Ethics, 100(1), 151-173. http://dx.doi.org/10.1007/s10551-011-0774-4

20. Sigurthorsson, D. (2012). The Icelandic Banking Crisis: A Reason to Rethink CSR? Journal of Business Ethics, 111(2), 147-156. http://dx.doi.org/10.1007/s10551-012-1207-8

21. Soana, M. G. (2011). The Relationship Between Corporate Social Performance and Corporate Financial Performance in the Banking Sector. Journal of Business Ethics, 104(1), 133-148. http://dx.doi.org/10.1007/s10551-011-0894-x

22. Yeung, S. (2011). The Role of Banks in Corporate Social Responsibility. Journal of Applied Economics and Business Research, 1(2), 103-115. http://www.aebrjournal.org/uploads/6/6/2/2/ 6622240/4.shirley.pdf

23. Watkins, J. P. (2011). Banking Ethics and the Goldman Rule. Journal of Economic Issues, 45(2), 363-372. http://dx.doi.org/10.2753/JEI0021-3624450213

24. PwC, (2010). Customer Experience Index - 2010. The state of retail banking following the financial crisis. Retrieved from: http://www.pwc.com/cz/en/tiskove-zpravy-2011/assets/customerexperience-index-2010-en.pdf

\section{Contact information}

Ing. Lenka Burianová, Bc. Jirí Paulík.

Tomas Bata University in Zlin, Faculty of Management and Economics

Mostni 5139, 76001 Zlin

Tel: +420576032417

Email:burian.lenka@gmail.com,paulik@fame.utb.cz 